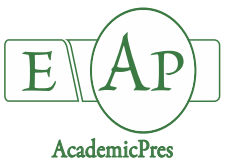

Benxue C et al. (2020)

Notulae Botanicae Horti Agrobotanici Cluj-Napoca 48(1):305-317

DOI: $10.15835 /$ nbha48111626

Research Article

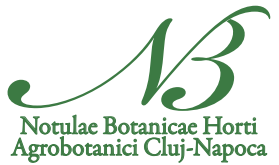

\title{
Effects of the interaction between shade and drought on physiological characteristics in Calamus viminalis seedlings
}

\author{
Benxue CHEN ${ }^{1 a}$, Yanbing $\mathrm{LI}^{2 \mathrm{~b}}$, Guanglu LIU ${ }^{1 *}$, Shaohui FAN ${ }^{1 *}$, \\ Haijun $Y_{A N G}^{3}$, Haoran $S^{1}$
}

${ }^{1}$ Key Laboratory for Bamboo and Rattan, International Center for Bamboo and Rattan, 100102, Beijing, China; benxuechen@126.com; liyanbing013@163.com; liuguanglu@icbr.ac.cn; fansh@icbr.ac.cn;shr@icbr.ac.cn

${ }^{2}$ Zhoukou Normal University, Design College, 6 Wenchang Road, Zhoukou, Henan 466001, China; liyanbing013@163.com

${ }^{3}$ Hainan Tropical Ocean University, Institute of Marine Science and Technology, 1 Yucai Road, 572022, Sanya, Hainan,

China; hyang@hntou.edu.cn ("correspondingauthors)

${ }_{a, b}$ These authors contributed equally to the work

\begin{abstract}
Recently, the endangerment of wild rattan population draws attention on the conservation and sustainable utilization of rattan resources. Rattan growing usually faces the light and water stress. Therefore, we aim to explore the combined effects of shade and drought on seedling growth, thus providing a theoretical ground for the conservation and artificial cultivation of the rattan. The combined effects of shade and drought on physiological and biochemical traits were studied in two-years-old Calamus viminalis seedlings. Photosynthetic indices including $\mathrm{Pn}, \mathrm{Gs}, \mathrm{Tr}$, and $\mathrm{Ci}$ and physiological indices including MDA, SOD, POD, CAT, and Pro were measured under four levels of water treatments and four levels of shade. Shade, drought and their interaction have a significant effect on C. viminalis seedlings growth. Generally, moderate shade could alleviate the impact induced by drought. However, mild drought usually enhances the effect caused by shading. The result showed that the shade decreased Pn, Gs, and Tr but increased Ci, MDA content and Pro content. Either with the shading or drought increasing, the activity of SOD, POD, and CAT firstly increase and then declined. Drought reduced Pn, Gs, Tr, and Ci but increased the content of MDA and Pro. Overall, the result suggests that $25-50 \%$ shading and $65 \%$ RSWC water treatment are most beneficial for the growth of $C$. viminalis seedlings.
\end{abstract}

Keywords: adversity resistance; antioxidant enzyme; low irradiance; photosynthesis; rattan seedlings; water deficiency Abbreviations: CAT: catalase; $\mathrm{Ci}$ : intercellular $\mathrm{CO}_{2}$ concentration; Gs: stomatal conductance; MDA: malondialdehyde; Pn: Net photosynthetic rate; POD: peroxidase; Pro: proline; SOD: superoxide dismutase; Tr: transpiration rate

\section{Introduction}

Rattans are a group of climbing plants assigned to Family Palmae, Calameae, widely distributed in IndoChina and Chinese tropical and sub-tropical forests (Jiang et al., 2007; Wang, 2015b). Rattans, so-called "green 
gold", are well known as an important non-timber product in southeastern Asia, most species of which are good material for handicraft and furniture. Moreover, some species' shoots and fruits can be made into food products. Notably, the rattan plantation and trade are of enormous economic value and developmental potential (Li et al., 2002; Jiang et al., 2007; Jiang, 2013; Wang, 2015b). However, the over-exploitation of rattan resources leads to its habitat loss and a dramatic drop of the natural rattan populations, thus largely impeding the development of rattan industry and trade (Jiang et al., 2007; Dong et al., 2015; Chen et al., 2017; Peng, 2017). The research to investigate physiological characteristics and the affecting factors of rattan seedling growth was called for better conservation of rattan resources and sustainable utilization.

Light and water supply are the most significant factors for the rattan seedling growing (Ingram and Bartels, 1996; Jiang et al., 2007; Liu et al., 2011). Many studies demonstrated that the seedlings of most rattan species are supposed to grow well under some extent of shade and different species are grown under a various degree of the irradiance (Mori, 1980; Yin et al., 1988; Dransfield, 1992; Sun et al., 2013). One-year-old Calamus manan seedlings grow well under 10\%-15\% shading (Mori, 1980). The most beneficial light condition for the growth of $C$. simplicifolius seedlings is $20 \%-50 \%$ relative light intensity while that of $C$. teradactylus is 50\%-60\% (Yin et al., 1988). Contrary to the former species, Daemonorops margaritae and C. rhabdocladus seedlings require very high relative light intensity about 80\% (Yin et al., 1988, 1993).

The water deficiency or drought was the main factor resulting in a remarkable reduction of rattan population (Yin et al., 1993; Li et al., 2002). The growth of most rattan species needs sufficient water supply, such as C. caesius (Manocaran, 1981a,b, 1982a,b). Only a few species like Daemonorops jenkinsiana and C. rhabdocladus have relatively high drought tolerance and can survive in less humidity condition (Yin et al., 1993; $\mathrm{Li}, 2003$ ). The combine effects of shade and drought on woody seedling have often been described and there is growing evidence that the shade and drought have a significant interactive effect on plant growth (Sack and Grubb, 2002; Aranda et al., 2005; Climent et al., 2006). However, the opinions on whether the drought stress has a stronger impact on seedling growth in deep shade or at higher irradiance are divergent (Holmgren, 2000; Sack and Grubb, 2002). One of the popular opinions is that moderate shade can improve plant performance under drought (Rousset and Lepart, 2000). Tree seedling survival under dry conditions was higher in shade than in high light thus providing support for this opinion (Amissah et al., 2015). In addition, the study on Arthraxon hispidus suggests that the interaction of some degree of shading and drought can facilitate the photosynthetic capacity, metabolic rate, and resistance potential (Sun et al., 2018). As for rattans, previous studies mostly concentrated on the effect of irradiance or water supply solely on the growth of rattan seedlings (Yin et al., 1988; Li et al., 2002, 2003; Sun et al., 2013; Dong et al., 2015), however, the interactive effect of the two factors on the growth of rattan seedlings remains unknown.

C. viminalis, widely distributed in southern Asia, is one of the excellent rattan species for the rattan plantation and industry. However, the research about its physiological characteristics and responses to shade and drought stress are still lacking. In the present study, C. viminalis seedlings were subjected to $2 \times 4$ factorial (shade, drought) experiment to test the interactive effects of shade and drought on seedling growth and their physiological resistance. We aim to provide a theoretical ground and support for the conservation and artificial cultivation of C. viminalis.

\section{Materials and Methods}

Plant growth conditions and experimental site

Two-years-old C. viminalis seedlings were collected from Hainan Zhongteng Co., Ltd., Hainan province, China. Each seedling was separately transplanted to a pot (diameter: $21 \mathrm{~cm}$; height: $19 \mathrm{~cm}$ ) with the same amount of red clay soil obtained from Ganzhaling, Hainan province. The physiological conditions of the 
soil were measured as follows. PH: 5.6, water content: $17.26 \%$, organic content: $11.4 \mathrm{~g}_{\mathrm{kg}}{ }^{-1}$, available $\mathrm{N}$ content: $127.75 \mathrm{mg} \cdot \mathrm{kg}^{-1}$, available phosphorus content: $7.13 \mathrm{mg} \cdot \mathrm{kg}^{-1}$, available potassium contents: $80.05 \mathrm{mg} \cdot \mathrm{kg}^{-1}$. The seedlings were grown at the greenhouse of Yongmao ecological breeding base, which located at Jiyang, Sanya in Hainan province $\left(109^{\circ} 35^{\prime} 41^{\prime \prime} \mathrm{E}, 18^{\circ} 19^{\prime} 21^{\prime \prime} \mathrm{N}\right)$ from 5 April to 21 June 2018.

\section{Experimental design}

After one-month establishment phase of the seedlings, the seedlings were subjected to $2 \times 4$ factorial (shade, drought) experiment for a total of 16 treatment combinations and each treatment had 15 pots (8 May 2018). The experiment consists of four water regimes: $85 \%$ relative soil water content (CK, W0), $65 \%$ RSWC (mild drought, W1), 45\% RSWC (moderate drought, W2) and 25\% RSWC (severer drought, W3) and four shade treatments: full sunlight (CK), 25\% shading, 50\% shading, and 75\% shading. For the water treatment, relative soil water content was measured by the soil moisture tester (TDR300, USA) at 15:00-18:00 every day and watered as needed to maintain soil moisture during the experiment. For the shade treatment, the seedlings are covered by the shade-cloth. Physiological indices were measured after 45 days of treatment.

\section{Physiological traits measurement}

Net photosynthetic rate $(P n)$, transpiration rate $(T r)$, intercellular $\mathrm{CO}_{2}$ concentration $(C i)$, and stomatal conductance $(G s)$ were measured by a portable photosynthesis system Li-6400 (Lincoln, USA) at 9:00-11:00 on sunny days. Five random replicates and from each of replicates three functional leaves were selected for measurement.

The content of MDA and Pro were measured by thiobarbital acid colorimetry and acid ninhydrin method respectively. The activity of SOD, POD, and CAT were measured using NBT method, guaiacol method and ultraviolet absorption method respectively. Three replicates were imposed for each index measurement.

\section{Statistical analyses}

All data were subjected to an analysis of variance and Duncan comparisons at a threshold $\mathrm{p}=0.05$ to test the differences between the treatments with an SPSS 20.0 (IBM, USA). All the graphs were created and processed by using Origin 8.5 .

\section{Results}

\section{Effects of the shade and drought on photosynthetic indices of Calamus viminalis seedlings}

With the shading degree increasing, the photosynthetic indices including the net photosynthetic rate $(\mathrm{Pn})$, stomatal conductance $(\mathrm{Gs})$, transpiration rate $(\mathrm{Tr})$ and intercellular carbon dioxide concentration $(\mathrm{Ci})$ all experienced an early raise and a subsequent decline (Table 1). For 25\% shading, $\mathrm{Tr}$ and Ci significantly increased whereas Pn and Gs showed no statistically significant difference ( $p>0.05)$. For 50\% shading, Pn decreased significantly by $30 \%$, however, $\mathrm{Tr}$ and Ci showed a significant increase by $12 \%$ and $8 \%$ respectively $(\mathrm{p}<0.05)$. A significant decrease was found for $\mathrm{Pn}, \mathrm{Gs}$, and $\operatorname{Tr}$ at $75 \%$ shading $(\mathrm{p}<0.05)$, where the decrease was $70 \%, 45 \%$, and $11 \%$ respectively. Pn and Gs reached a peak at 25\% shading while $\mathrm{Tr}$ and $\mathrm{Ci}$ experienced the greatest increase at $50 \%$ shading. Conclusively, all the photosynthetic indices were found significantly declined at $75 \%$ shading.

Drought decreased Tr and Ci. And Pn and Gs increased under W1 but decreased under W2 (Table 1). Under mild drought (W1), Pn and Gs significantly increased by $27 \%$ and $47 \%$ respectively compared to control group $(\mathrm{p}<0.05)$ but $\mathrm{Tr}$ and $\mathrm{Ci}$ markedly decreased by $9 \%$ and $12 \%$ respectively. Under moderate drought (W2), Tr and Ci showed a significant decline by $34 \%$ and $15 \%$ respectively but Pn showed no significant 
308

decrease from the control group. When the seedlings submitted to the severe drought (W3), water deficiency induced a prominent decrease for $\mathrm{Pn}, \mathrm{Gs}$, Tr, and $\mathrm{Ci}$ by $67 \%, 64 \%, 65 \%$, and $20 \%$ respectively.

Table 1. Effects of different levels of shade and drought on photosynthetic parameters of seedlings

\begin{tabular}{|c|c|c|c|c|c|}
\hline \multirow{2}{*}{ Index } & \multirow{2}{*}{$\begin{array}{c}\text { Drought } \\
\text { stress }\end{array}$} & \multicolumn{4}{|c|}{ Shade degree/\% } \\
\hline & & 0 & 25 & 50 & 75 \\
\hline \multirow{4}{*}{$\begin{array}{l}\text { Photosynthetic } \\
\text { rate } /\left(\mu \mathrm{mol} \cdot \mathrm{m}^{-2} \cdot \mathrm{s}^{-1}\right) \\
\left(P_{n}\right)\end{array}$} & W0 & $2.44 \pm 0.17 \mathrm{ABa}$ & $2.91 \pm 0.14 \mathrm{Ba}$ & $1.67 \pm 0.42 \mathrm{ABb}$ & $0.74 \pm 0.07 \mathrm{Bc}$ \\
\hline & W1 & $3.13 \pm 0.15 \mathrm{Ab}$ & $4.55 \pm 0.52 \mathrm{Aa}$ & $2.01 \pm 1.12 \mathrm{Ac}$ & $1.12 \pm 0.15 \mathrm{Ac}$ \\
\hline & W2 & $1.75 \pm 0.08 \mathrm{Bb}$ & $3.01 \pm 0.14 \mathrm{Ba}$ & $1.01 \pm 0.02 \mathrm{Bc}$ & $0.19 \pm 0.03 \mathrm{Cd}$ \\
\hline & W3 & $0.81 \pm 0.05 \mathrm{Cb}$ & $1.89 \pm 0.06 \mathrm{Ca}$ & $0.72 \pm 0.11 \mathrm{Cb}$ & $0.17 \pm 0.09 \mathrm{Cc}$ \\
\hline \multirow{4}{*}{$\begin{array}{c}\text { Stomatal } \\
\text { conductance / } \\
\left(\mathrm{mmol} \cdot \mathrm{m}^{-2} \cdot \mathrm{s}^{-}\right) \\
\left(G_{s}\right)\end{array}$} & W0 & $0.11 \pm 0.04 \mathrm{ABab}$ & $0.13 \pm 0.07 \mathrm{ABa}$ & $0.08 \pm 0.01 \mathrm{Abc}$ & $0.06 \pm 0.01 \mathrm{ABc}$ \\
\hline & W1 & $0.14 \pm 0.05 \mathrm{Aa}$ & $0.16 \pm 0.06 \mathrm{Aa}$ & $0.10 \pm 0.03 \mathrm{Aab}$ & $0.09 \pm 0.05 \mathrm{Ab}$ \\
\hline & W2 & $0.09 \pm 0.01 \mathrm{Bab}$ & $0.12 \pm 0.03 \mathrm{Ba}$ & $0.09 \pm 0.02 \mathrm{Aab}$ & $0.07 \pm 0.03 \mathrm{ABb}$ \\
\hline & W3 & $0.04 \pm 0.01 \mathrm{Cb}$ & $0.09 \pm 0.01 \mathrm{Ba}$ & $0.04 \pm 0.01 \mathrm{Bb}$ & $0.05 \pm 0.02 \mathrm{Bb}$ \\
\hline \multirow{4}{*}{$\begin{array}{c}\text { Intercellular } \mathrm{CO}_{2} \\
\text { concentration / } \\
\left(\mu \mathrm{mol} \cdot \mathrm{mol}^{-}\right) \\
\left(\mathrm{C}_{i}\right)\end{array}$} & W0 & $317.86 \pm 17.22 \mathrm{Abc}$ & $322.53 \pm 5.69 \mathrm{Ab}$ & $344.31 \pm 9.45 \mathrm{ABa}$ & $312.66 \pm 11.29 \mathrm{ABc}$ \\
\hline & W1 & $289.74 \pm 13.15 \mathrm{Bc}$ & $340.58 \pm 14.25 \mathrm{Ab}$ & $382.86 \pm 39.46 \mathrm{Aa}$ & $325.46 \pm 8.24 \mathrm{Abc}$ \\
\hline & W2 & $271.04 \pm 10.41 \mathrm{Bd}$ & $332.36 \pm 7.44 \mathrm{Ab}$ & $370.87 \pm 6.39 \mathrm{Aa}$ & $316.28 \pm 21.67 \mathrm{ABc}$ \\
\hline & W3 & $254.62 \pm 31.16 \mathrm{Cc}$ & $333.19 \pm 13.03 \mathrm{Aa}$ & $314.38 \pm 30.12 \mathrm{Ba}$ & $279.71 \pm 25.51 \mathrm{Bb}$ \\
\hline \multirow{4}{*}{$\begin{array}{l}\text { Transpiration } \\
\text { rate } /\left(\mathrm{mmol} \cdot \mathrm{m}^{-2} \cdot \mathrm{s}^{-}\right) \\
\left(T_{r}\right)\end{array}$} & W0 & $2.04 \pm 0.13 \mathrm{Ab}$ & $2.11 \pm 0.42 \mathrm{Aab}$ & $2.28 \pm 0.17 \mathrm{Aa}$ & $1.81 \pm 0.05 \mathrm{Ac}$ \\
\hline & W1 & $1.79 \pm 0.08 \mathrm{Bb}$ & $2.09 \pm 0.65 \mathrm{ABa}$ & $2.12 \pm 0.16 \mathrm{ABa}$ & $1.65 \pm 0.26 \mathrm{ABb}$ \\
\hline & W2 & $1.35 \pm 0.09 \mathrm{Cc}$ & $1.82 \pm 0.08 \mathrm{Bb}$ & $2.09 \pm 0.23 \mathrm{ABa}$ & $1.24 \pm 0.17 \mathrm{Bc}$ \\
\hline & W3 & $0.72 \pm 0.04 \mathrm{Dc}$ & $1.42 \pm 0.35 \mathrm{Cb}$ & $2.01 \pm 0.39 \mathrm{Ba}$ & $0.87 \pm 0.11 \mathrm{Cc}$ \\
\hline
\end{tabular}

Note: Different capital letters in the same row indicate significant difference among the drought treatments at $\mathrm{p}<0.05$ level, and different lower case letters in the same row indicate significant difference among the luminousness at $\mathrm{p}<0.05$ level ( $\mathrm{n}=12)$; W0: enough moisture; W1: mild drought; W2: moderate drought; W3: severe drought.

The interactive effects of shade and drought were significant for the growth of $C$. viminalis seedlings. The moderate shade can alleviate the drought influences on seedlings. Twenty-five shading can reduce the decrease of $\mathrm{Pn}, \mathrm{Gs}, \mathrm{Tr}$, and $\mathrm{Ci}$ induced by drought, however, 50\% shading enhanced the reduction of all the photosynthetic indices. Meanwhile, mild drought (W1) significantly increased Pn at 25\% shading ( $<<0.05)$, whereas significantly decreased $\mathrm{Pn}$ at $75 \%$ shading $(\mathrm{p}<0.05)$. Moderate drought (W2) significantly reduced $\mathrm{Pn}$, $\operatorname{Tr}$ at $75 \%$ shading $(\mathrm{p}<0.05)$. A significant reduction of $\mathrm{Pn}, \mathrm{Tr}, \mathrm{C}$, and $\mathrm{Gs}$ was observed by $93 \%, 51 \%, 55 \%$, and $83 \%$ respectively under the severe water stress (W3) and lowest irradiance ( $75 \%$ shading) $(\mathrm{p}<0.05)$. In concluding, $C$. viminalis seedlings exhibited the greatest $\operatorname{Pn}\left(4.55 \mu \mathrm{mol} \cdot \mathrm{m}^{-2} \cdot \mathrm{s}^{-1}\right)$ under $25 \%$ shading and mild drought (W1).

The double factor variance analysis suggests the shade and drought both have highly significant effects on photosynthetic indices $(\mathrm{p}<0.001)$ (Table. 2). The examining value of $F$ shows that the influence of shade has the ranking as follows $C i>P n>\operatorname{Tr}>G$ s. The influence of drought has the same ranking as shade. A distinct interaction of shade $\times$ drought is also shown in Table $2(\mathrm{p}<0.001)$ with a ranking $\operatorname{Tr}>C i>P n>G s$.

\section{Effects of shade and drought on the content of MDA in C. viminalis leaves}

Shade led to a reduction of the content of MDA in C. viminalis seedlings under $25 \%$ and $50 \%$ shade degree by $10 \%$ and $8 \%$ respectively while a significant increase under $75 \%$ shade degree by $17 \%(P<0.05)$ (Fig. 1). Drought stress increasingly raised the content of MDA in $C$. viminalis seedlings. Mild drought didn't induce a significant increase in the content of MDA ( $p>0.05)$. Moderate drought and severer drought led to a significant increase in the content of MDA in seedlings by $31 \%$ and $42 \%$ respectively in response to water deficiency $(\mathrm{p}<0.05)$. 
Table 2. Double factor variance analysis on photosynthetic indices. The photosynthetic rate, stomatal conductance, intercellular CO2 concentration and transpiration rate were measured in $(\mathrm{Pn}) /(\mu \mathrm{mol} \cdot \mathrm{m}-2 \cdot \mathrm{s}-1)$, $(\mathrm{Gs}) /(\mathrm{mmol} \cdot \mathrm{m}-2 \cdot \mathrm{s}-1),(\mathrm{Ci}) /(\mu \mathrm{mol} \cdot \mathrm{mol}-1)$, and $(\mathrm{Tr}) /(\mathrm{mmol} \cdot \mathrm{m}-2 \cdot \mathrm{s}-1)$ respectively

\begin{tabular}{|c|c|c|c|c|c|}
\hline \multicolumn{2}{|c}{ Item } & $\begin{array}{c}\text { Photosynthetic } \\
\text { rate }\end{array}$ & $\begin{array}{c}\text { Stomatal } \\
\text { conductance }\end{array}$ & $\begin{array}{c}\text { Intercellular } \mathrm{CO}_{2} \\
\text { concentration }\end{array}$ & $\begin{array}{c}\text { Transpiration } \\
\text { rate }\end{array}$ \\
\hline \multirow{2}{*}{ Shade } & $\mathrm{F}$ & 89.355 & 8.411 & 259.412 & 11.651 \\
\cline { 2 - 6 } & $\mathrm{p}$ & $<0.001$ & $<0.001$ & $<0.001$ & $<0.001$ \\
\hline \multirow{2}{*}{ Drought } & $\mathrm{F}$ & 94.656 & 16.343 & 342.176 & 78.243 \\
\cline { 2 - 6 } & $\mathrm{p}$ & $<0.001$ & $<0.001$ & $<0.001$ & $<0.001$ \\
\hline \multirow{2}{*}{ Shade $\times$ Drought } & $\mathrm{F}$ & 9.466 & 4.093 & 17.624 & 39.175 \\
\cline { 2 - 6 } & $\mathrm{P}$ & $<0.001$ & $<0.001$ & $<0.001$ & $<0.001$ \\
\hline
\end{tabular}

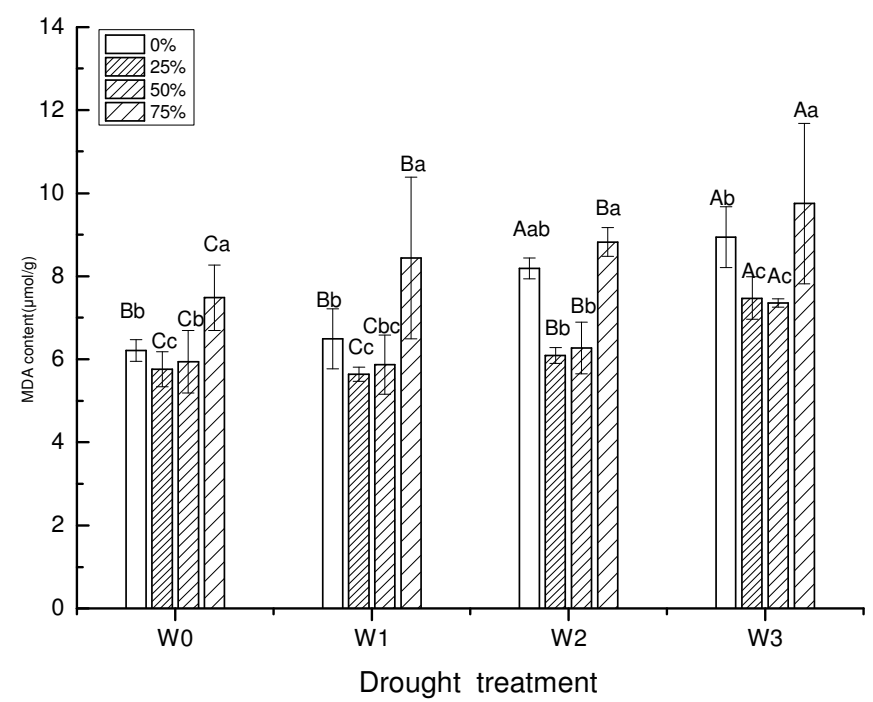

Figure 1. Effects of different shade and drought on MDA content of $C$. viminalis

Moreover, a significant interactive effect of shade and drought was found on the content of MDA $(\mathrm{p}<0.05)$. Twenty-five shading can reduce the growing of MDA induced by drought. By contrast, more than $50 \%$ shading would assist in the promotion of MDA under drought stress in seedlings. On the other hand, mild drought stress promoted the increase of MDA significantly at 75\% shading. The content of MDA increased significantly by $60 \%$ compared with the control group under the combined effect of severe drought and lowest irradiance.

The variance analysis indicates that shade and drought have a highly significant influence on the content of MDA in C. viminalis seedlings. The magnitude of influence ranks as follows Shade $>$ Drought $>$ Shade $>$ Drought (Table 3).

Table 3. Double factor variance analysis on MDA

\begin{tabular}{|c|c|c|c|c|c|c|}
\hline \multirow{2}{*}{ Item } & \multicolumn{2}{|c|}{ Shade } & \multicolumn{2}{c|}{ Drought } & \multicolumn{2}{c|}{ Shade $\times$ Drought } \\
\cline { 2 - 7 } & $\mathrm{F}$ & $\mathrm{p}$ & $\mathrm{F}$ & $\mathrm{p}$ & $\mathrm{F}$ & $\mathrm{p}$ \\
\hline $\begin{array}{c}\text { Malondialdehyde } \\
(\mathrm{MDA}) /(\mu \mathrm{mol} / \mathrm{g})\end{array}$ & 12.809 & 0.001 & 19.613 & $<0.001$ & 4.313 & $<0.001$ \\
\hline
\end{tabular}


Effects of shade and drought on the activity of SOD, POD, and CAT of C. viminalis leaves

With shading increasing, the activity of superoxide dismutase (SOD), peroxidase (POD), and catalase (CAT) increased first and then declined (Fig. 2). The activity of SOD increased significantly by $12 \%$ compared with the control group at $25 \%$ shading $(\mathrm{p}<0.05)$. For $50 \%$ shading, the activity of SOD and POD have observed a prominent increase by $39 \%$ and $25 \%$ respectively $(\mathrm{p}<0.05)$. However, the activity of SOD, POD, and CAT show no significant difference ( $p>0.05$ ) at $75 \%$ shading. Mild drought (W1) and moderate drought (W2) increased the activity of SOD significantly by $26 \%$ and $23 \%$ respectively $(\mathrm{p}<0.05)$. On the contrary, the activity of SOD, POD, and CAT declined but not significantly under the severe drought (W3) ( $>0.05)$.

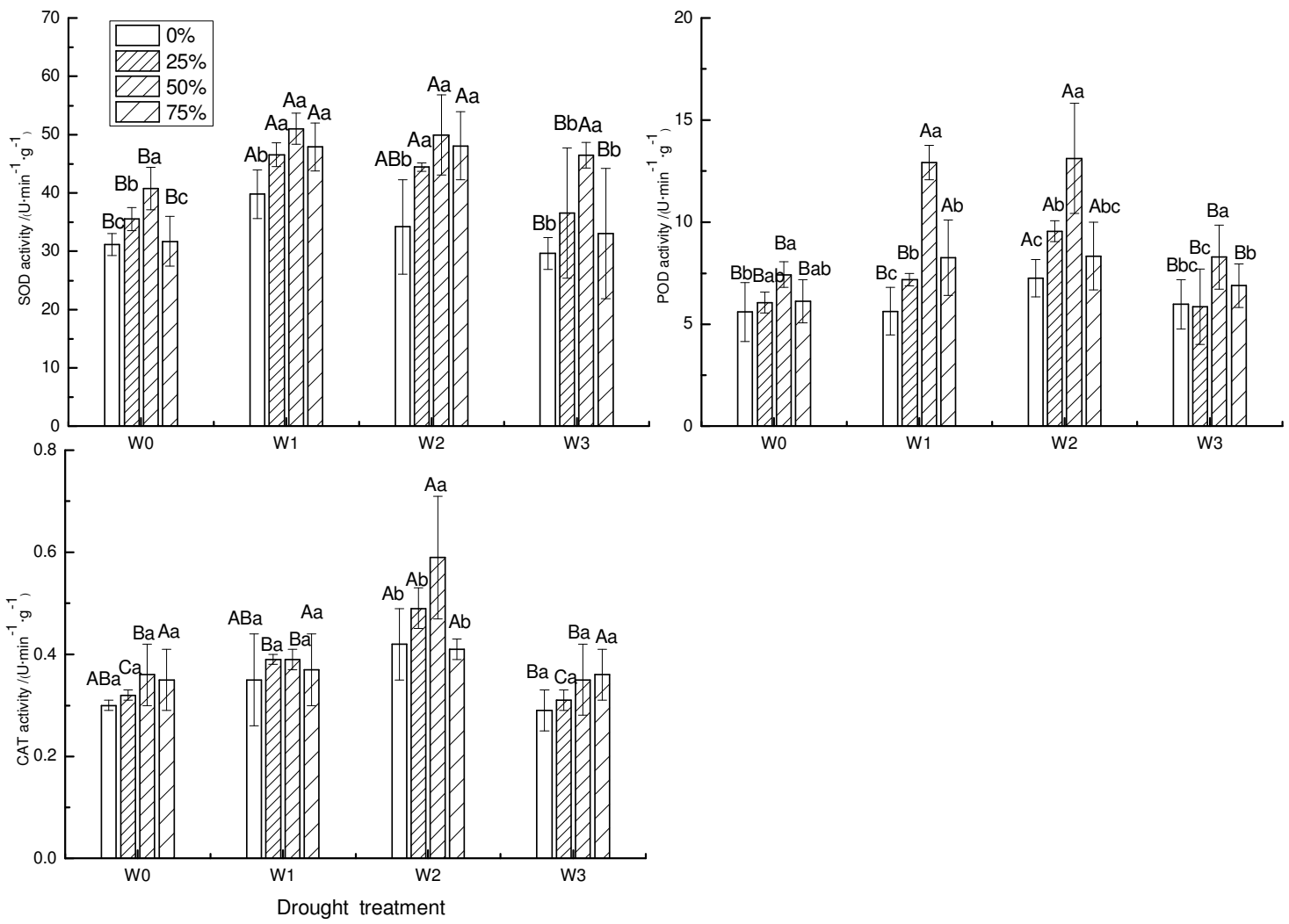

Figure 2. Effects of different shade and drought on the antioxidase activity of $C$. viminalis

The interactive effect of shade and drought was significant for the activities of SOD, POD, and CAT $(\mathrm{p}<0.05)$. The greatest activity of SOD was observed when seedlings submitted to $50 \%$ shading and moderate drought, with an increase up to 66\% of the control group. The activity of POD and CAT reached a peak at $50 \%$ shading and moderate drought, increasing by $134 \%$ and $97 \%$ respectively. The combined effect of deep shading (75\% shading) and severer drought (W3) significantly declined the activity of SOD, POD, and CAT.

The variance analysis suggests that shade and drought have highly significant effects on the activity of SOD, POD, and CAT $(\mathrm{p}<0.01)$ (Table 4). The effects of shading on antioxidase rank as follows SOD $>$ CAT $>$ POD and the effects of drought rank $\mathrm{SOD}>\mathrm{POD}>\mathrm{CAT}$. The interaction of shade and drought was prominent for the activity of SOD and POD, however not significant for that of CAT, where the ranking of effects is $\mathrm{SOD}>\mathrm{POD}>\mathrm{CAT}$. 
Table 4. Two ways variance analysis of antioxidase activity. The superoxide dismutase, peroxidase activity and gatalase activity were measured in (SOD)/(U. $\left.\mathrm{min}^{-1} \cdot \mathrm{g}^{-1}\right),(\mathrm{POD}) /$

$\left(\mathrm{U} \cdot \mathrm{min}^{-1} \cdot \mathrm{g}^{-1}\right)$ and $(\mathrm{CAT}) /\left(\mathrm{U} \cdot \mathrm{min}^{-1} \cdot \mathrm{g}^{-1}\right)$ respectively

\begin{tabular}{|c|c|c|c|c|}
\hline \multicolumn{2}{|c|}{ Item } & $\begin{array}{c}\text { Superoxide } \\
\text { dismutase }\end{array}$ & $\begin{array}{c}\text { Peroxidase } \\
\text { activity } \\
\text { activity }\end{array}$ \\
\hline \multirow{2}{*}{ Shade } & $\mathrm{F}$ & 40.88 & 7.936 & 8.867 \\
\cline { 2 - 5 } & $\mathrm{p}$ & $<0.001$ & 0.001 & 0.002 \\
\hline \multirow{2}{*}{ Drought } & $\mathrm{F}$ & 103.451 & 9.832 & 6.126 \\
\cline { 2 - 5 } & $\mathrm{p}$ & $<0.001$ & $<0.001$ & $<0.001$ \\
\hline \multirow{2}{*}{ Shade $\times$ drought } & $\mathrm{F}$ & 4.632 & 3.109 & 0.091 \\
\cline { 2 - 5 } & $\mathrm{p}$ & 0.041 & 0.026 & 1.438 \\
\hline
\end{tabular}

\section{Effects of shade and drought on the content of proline of C. viminalis leaves}

The content of proline was observed no significant difference when submitted to $50 \%$ shading $(\mathrm{p}>0.05)$. However, $75 \%$ shading increased proline significantly by $46 \%(\mathrm{p}<0.05)$. The drought stress significantly increased the content of proline, which increases up to $46 \%, 77 \%$, and $108 \%$ respectively under mild drought (W1), moderate drought (W2) and severe drought (W3) stress.

Shade and drought have a significant interactive effect on the content of proline $(\mathrm{p}<0.05)$. The increase of proline was reduced at $25 \%$ shading, however, increased at $50 \%$ and $75 \%$ shading. Drought stress greatly further increased the growing of the proline induced by shading. Mild drought (W1) significantly increased the content of proline at $50 \%$ shading. The severe drought (W3) and the lowest irradiances induced a significant increase of proline by $161 \%$ compared with the control group (Fig. 3).

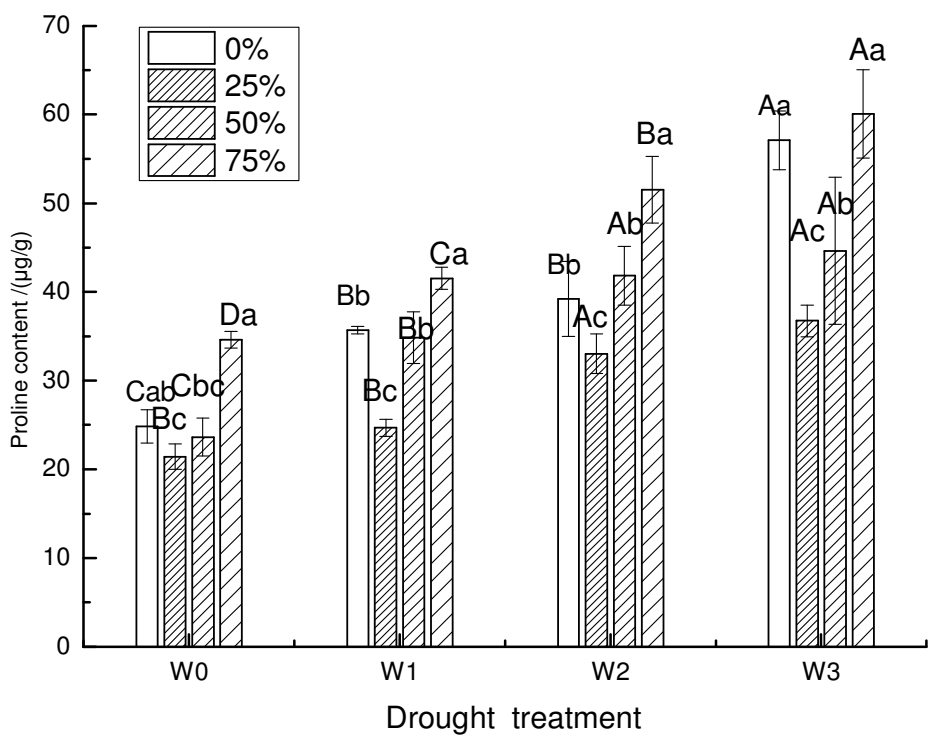

Figure. 3. Effects of different shading and drought on proline content of $C$. viminalis

The variance analysis showed that shade and drought both have a highly significant effect on proline $(\mathrm{p}<0.01)($ Table 5), ranking as Drought $>$ Shade $>$ Shade $\times$ Drought. 
Table 5. Double factor variance analysis on proline content

\begin{tabular}{|c|c|c|c|c|c|c|}
\hline \multirow{2}{*}{ Item } & \multicolumn{2}{|c|}{ Shade } & \multicolumn{2}{c|}{ Drought } & \multicolumn{2}{c|}{ Shade $\times$ Drought } \\
\cline { 2 - 6 } & $\mathrm{F}$ & $\mathrm{p}$ & $\mathrm{F}$ & $\mathrm{p}$ & $\mathrm{F}$ & $\mathrm{p}$ \\
\hline $\begin{array}{c}\text { Proline content } \\
(\text { Pro }) /(\mu \mathrm{g} / \mathrm{g})\end{array}$ & 12.809 & $<0.001$ & 19.613 & $<0.001$ & 4.313 & $<0.001$ \\
\hline
\end{tabular}

\section{Discussion}

\section{Effects of shade and drought on photosynthesis}

Shading impacts the photosynthesis by reducing the light intensity and duration and regulating the transpiration rate and stomatal closure (Tang et al., 2013). The present study shows that shading has a significant influence on the photosynthesis of $C$. viminalis seedlings. With the shading degree increasing, Pn, Gs, $\mathrm{Tr}$, and $\mathrm{Ci}$ increased first and then declined. Pn and Gs reached a peak at 25\% shading while $\mathrm{Tr}$ and $\mathrm{Ci}$ reached a peak at $50 \%$ shading (Table 1 ). Therefore, the growth of $C$. viminalis seedlings favors some extent of shading, especially among the range of $25 \%-50 \%$. This result agrees with the general opinion that moderate shading could facilitate the growth of rattan seedlings but overshading is greatly harmful to its growth (Bøgh, 1996; Yin et al., 1998). However, different species have various shading tolerance. C. manan, C. simplicifolius, and $C$. teradactylus have similar shading tolerance with C. viminalis, approximately ranging from $20 \%-65 \%$ (Mori, 1980; Yin et al., 1988, 1993; Sun et al., 2013). C. gracilis seedlings can grow well under up to $75 \%$ shading (Dong et al., 2015). By contrast, C. rhabdocladus seedling growth requires very high light intensity up to $80 \%$ full light (Yin et al., 1993).

Water stress leads to the reduction of photosynthetic material transportation, thus directly decreasing the efficiency of photosynthesis (Lawlor, 1995; Han et al., 2014; Yuan et al., 2016). In the present study, with an increasing degree of water stress, Pn and Gs increased first but then declined. The result is not confirmed to the opinion that mild drought decreases photosynthetic capacity (Yang et al., 2007; Dai et al., 2009). Contrarily the mild drought (W1) could promote Pn and Gs to the greatest value in the present study (Table 1) (Deng et al., 2016). And water stress started to decrease Pn and Gs from moderate drought (W2) but not significantly. A significant decline of $\mathrm{Pn}, \mathrm{Gs}, \mathrm{Tr}$, and Ci was observed only when seedlings submitted to severe drought (W3) (Table 1). Therefore, the result suggests that $C$. viminalis seedlings have relatively high drought tolerance.

A significant interactive effect of shading and drought on the growth of $C$. viminalis seedlings was observed in the present study. Mild drought (W1) could generally improve the photosynthetic capacity. On the other hand, $25 \%$ shading could alleviate the decrease of photosynthetic capacity induced by drought. But the interaction of overshading and severer drought could lead to marked reduction of the photosynthetic capacity. The same result was also observed in Arthraxon hispidus (Sun et al., 2018.)

\section{Effects of shade and drought on the content of MDA}

The content of MDA is an indicator of membrane lipid peroxidation, reflecting the degree of cell membrane damage in response to the light or water stress (Chen, 1989; Yang et al., 2017). The MDA content would dramatically increase in the plant when the plant is at an adverse condition (Wei et al., 2014; Liu et al., 2018). In the paper, the MDA content at $25 \%$ shading was even lower than that of the control group (Fig. 1). The MDA content started to increase at $50 \%$ shading but still lower than that of the control group (Fig. 1). However, when the seedlings submitted to $75 \%$ shading, the MDA content remarkably increased to its maximum value (Fig. 1). Therefore, $25 \%$ shading could promote the performance of the seedling, but $50 \%$ shading is a threshold that would do harm to the growth of seedlings. 
On the other hand, the drought stress induces a significant increase in MDA content (Wang et al., 1990; 2006; 2013). Moderate drought and severe drought lead to a prominent increase of MDA content, suggesting an enhancement of lipid peroxidation in cells (Sang et al., 2011; Qian et al., 2015; Jia et al., 2015, 2018). The similar result was found in the study of Rhodiola kirilowii seedlings (Yang et al., 2017). The interactive effect of shading and drought is significant on the growth of C. viminalis seedlings. Low irradiance like $25 \%$ shading could lower the MDA content, thus alleviating the damage caused by drought on the cell membrane. However, more than $50 \%$ shading would augment the MDA content induced by drought.

\section{Effects of shade and drought on the activity of SOD, POD, and CAT}

The antioxidant enzyme system, including SOD (superoxide dismutase), POD (Peroxidase) and CAT (catalase), is an important and complicated protective mechanism of plants against the adverse condition (Wu et al., 2016). When plants are facing water or light stress, the activity of SOD, POD, and CAT are promoted to decrease the damage induced by the environment stress (Wu et al., 2016; Sun et al., 2018). The activity of SOD, POD, and CAT generally show an increasing trend at the early stage under stress. The activity of SOD, POD, and CAT started to increase significantly at $25 \%$ shading and decline at $75 \%$ shading but not significantly (Table 4). Different plant species differ in the responding order and magnitude of the antioxidant enzyme system under stress. In Arthraxon hispidus, the activity of POD significantly increased at $10 \%$ shading whereas that of $C$. viminalis significantly increased at 30\% shading (Sun et al., 2018). Moreover, the activities of SOD, POD, and CAT in Arthraxon hispidus prominently decreased at 70\% shading, however, those of $C$. viminalis declined at $75 \%$ shading but not significantly (Sun et al., 2018.). Probably, the C. viminalis seedlings have a higher resistance than Arthraxon hispidus under low irradiance.

For the drought stress, the activity of SOD was promoted significantly when facing mild drought (W1) and the activity of POD increased significantly when seedlings submitted to moderate drought (W2) (Table 4). Under severe drought, the activity of SOD, POD, and CAT all experienced a decline but the decreases are not significant (Table 4). Consequently, C. viminalis seedlings may have powerful antioxidant enzyme regulating ability to protect plants from damage induced by adverse conditions. However, when the interactive effect of deep shading and severer drought obviously exceeds the threshold of the regulation of antioxidant enzyme system, the activity of SOD, POD and CAT significantly decline (Jing et al., 2013; Li et al., 2014; Ren et al., 2017). This strong combined effect is also observed in Arthraxon hispidus (Sun et al., 2018).

\section{Effects of shade and drought on the content of proline}

The content of free proline, an important osmolyte, plays a vital role in regulating the osmotic pressure of the plant cell and alleviating the damage induced by adverse condition (Ren et al., 2000; Mahajan and Tuteja, 2005; Haffani et al., 2014). In this study, Pro had lower content than the control group at $25 \%$ and $50 \%$ shading but increased significantly by $46 \%$ at $75 \%$ shading. That suggests the damage induced by full light and deep shading triggers the great accumulation of Pro in the plant (Arora and Saradhi, 2002; Xue et al., 2011; Xie et al., 2013).

The drought has a greater impact on the content of Pro than shading. The water stress significantly increased the content of Pro at mild drought, moderate drought, and severe drought by $46 \%, 77 \%$, and $108 \%$ respectively (compared with the control group). The accumulation of Pro can protect plant cell from peroxidative processes induced by water stress through osmotic regulation (Shao et al., 2006; Liu et al., 2007; Sang et al., 2011; Hou et al., 2014). This result is supported by many studies in terms of maize, sorghum, Arthraxon hispidus and Eucommia ulmoides (Shao et al., 2006; Liu et al., 2007; Sun et al., 2018). The interaction of shading and drought exert great influences on the content of Pro. Twenty-five percent shading could

alleviate the impact induced by drought, but more than $50 \%$ shading enhances the accumulation of Pro caused by drought. This result is in full accordance with the recent study on Arthraxon hispidus (Sun et al., 2018). 


\section{Conclusions}

Shade, drought and their interaction have a significant effect on $C$. viminalis seedlings growth. Generally, moderate shade could alleviate the impact induced by drought. However, mild drought usually enhances the effect caused by shading. The interactive effect of deep shading and severe drought leads to a significant decrease of the photosynthetic capacity, the decrease of the activity of the antioxidant enzyme and the accumulation of MDA and Pro. When facing the light and water stress, the seedling adjusts itself by regulating photosynthetic indices, enhancing the activity of antioxidant enzyme system, and increasing Pro content to reduce the damage and gradually establish a protective mechanism to adapt the adverse conditions. The result shows that $C$. viminalis seedlings have relatively high shading and drought resistance and $25 \%-50 \%$ shading and $65 \%$ relative soil water content is most beneficial for $C$. viminalis seedlings growth. As a result, $C$. viminalis seedlings are more favorably planted in well-drained soil and moderate shade condition than poorlydrained soil and full light condition. When rattans are grown in the natural high-density forests, proper weeding and thinning the crown of the trees would facilitate their growth.

\section{Acknowledgements}

This research was supported by the special funds 'Tropical bamboo and rattan resources collection and preservation research' (1632017007) and 'Population structure research of the natural regeneration rattans in Hainan’ (1632016014) from International Center for Bamboo and Rattan.

\section{Conflict of Interest}

The authors declare that there are no conflicts of interest related to this article.

\section{References}

Amissah L, Mohren GMJ, Kyereh B, Poorter L (2015). The effects of drought and shade on the performance, morphology and physiology of Ghanaian tree species. PLoS ONE 10(4):e0121004.

Aranda I, Castro L, Pardos M, Gil L, Pardos JA (2005). Effects of the interaction between drought and shade on water relations, gas exchange and morphological traits in cork oak (Quercus suber L.) seedlings. Forest Ecology and Management 210(1-3):117-129.

Arora S, Saradhi PP (2002). Light induced enhancement in proline levels under stress is regulated by non-photosynthetic events. Biologia Plantarum 45(4):629-632.

Bøgh A (1996). Abundance and growth of rattans in Khao Chong National Park, Thailand. Forest Ecology and Management 84(1-3):71-80.

Chen SY (1989). Membrane-lipid peroxidation and plant stress. Chinese Bulletin of Botany 6(4):211217.

Chen RG, Fan SH, Liu GL, Xu RJ, Hu X, Su HR (2017). Niche characteristics of dominant species of rattan accompanying community in secondary lowland rain forest in Hainan Island, China. Acta Botanica Boreali-Occidentalia Sinica 37(6):1226-1233.

Climent JM, Aranda I, Alonso J, Pardos JA, Gil L (2006). Developmental constraints limit the response of Canary Island pine seedlings to combined shade and drought. Forest Ecology and Management 231(13):164-168. 
Dai YJ, Shen ZG, Li Y (2009). Effects of shade treatments on the photosynthetic capacity, chlorophyll fluorescence, and chlorophyll content of Tetrastigma hemsleyanum Diels et Gilg. Environmental and Experimental Botany 65(2-3):177-182.

Deng YP, Lei JP, Pan L, Wang XR (2016). Model fitting of photosynthetic light-response curves in different Quercus variabilis provenances and its parameter comparison. Chinese Journal of Ecology 35(2):387394.

Dong SF, Lu J, Peng YW (2015). Effect of shading and fertilization on seedling growth of Calamus gracilis. Journal of West China Forestry Science 44(5):90-95.

Dransfield J (1992). The ecology and natural history of rattans. In: A guide to the cultivation of rattan. Wan RWM, Dransfield J, Manokaran N. Forest Record No. 35. Kuala Lumpur, Malaysia: Forest Research Insititute Malaysia pp 29.

Haffani S, Mezni M, Slama I, Ksontini M, Chaïbi W (2014). Plant growth, water relations and proline content of three vetch species under water-limited conditions. Grass and Forage Science 69(2):323-333.

Han B, Li ZY, Guo H, Zhang JP (2014). Studies on seedling photosynthetic characteristics of five tree species under drought Stress. Forest Research 27(1):92-98.

Holmgren M (2000). Combined effects of shade and drought on tulip poplar seedlings: trade-off in tolerance or facilitation? Oikos 90(1):67-78.

Hou ST, Zhang Q, Liu SC, Zeng LY, Wu Y, Liu GL (2014). Growth and physiological responses of Melaleuca bracteata cv. 'Revolution Gold' to water stress. Acta Botanica Boreali-Occidentalia Sinica 34(12):2491-2499.

Ingram J, Bartels D (1996). The molecular basis of dehydration tolerance in plant. Annual Review of Plant Physiology and Plant Molecular Biology 47(1):377-403.

Jia X, Sun CS, Li GY, Li GB, Chen GL (2015). Effects of progressive drought stress on the physiology, antioxidative enzymes and secondary metabolites of Radix Astragali. Acta Physiologiae Plantarum 37(12):262.

Jia X, Sun CS, Li GY, Li GB, Chen GL (2018). Effect of drought stress on the growth and physiological characteristics and the accumulation of astragaloside IV secondary metabolites of Astragalus membranaceus (Fisch.) var. mongholicus (Bge.) Hsiao. Acta Botanica Boreali-Occidentalia Sinica 38(3):501-509.

Jiang ZH, Fan SH, Zhang CS, Guan FY (2007). Advances in rattan research. Acta Agriculturae Univeritatis Jiangxiensis 29(6):957-964.

Jiang ZH, Wang KL (2013). Rattan in China. Science Press, Beijing.

Jing DW, Xing SJ, Du ZJ, (2013). Effects of drought stress on the growth, photosynthetic characteristics, and active oxygen metabolism of poplar seedlings. Chinese Journal of Applied Ecology 24(7):1809-1816.

Lawlor DW (1995). The effects of water deficit on photosynthesis. Environment and Plant Metabolism 129-160.

Li RS, Xu HC, Yang JC, Yin GT (2002). A review of relationship between rattan and water. Forestry studies in China 4(1):65-68.

Li RS (2003). Study on drought resistance and water use efficiency of three rattan species in southern China. PhD Thesis, Research Institute of Tropical Forestry, Chinese Academy of Forestry, Guangzhou.

Li YJ, Li J, Xu P, He HW (2014). Physiological responses of Lycium ruthenicum Murr. seedlings to drought stress. Arid Zone Research 31(4):756-762.

Liu JF, Yang WJ, Jiang ZP, Guo QS, Jin JQ, Xue L (2011). Effects of shading on photosynthetic characteristics and chlorophyll fluorescence parameters in leaves of the endangered plant Thuja sutchuenensis. Acta Ecologica Sinica 31(20):5999-6004.

Liu JL, Wang Y, Xu DM (2018). Study on physiological characteristics of five gramineous grass seedlings under drought stress. Pratacultural Science 35(5):1106-1115. 
Liu HY, Liang ZS, Liu SM, Dong JE (2007). Effect of progressive drying and rewatering on protective enzyme activities and osmoregulatory molecules in leaves of Eucommia ulmoides seeding. Journal of Northwest Forestry University 22(3):55-59.

Mahajan S, Tuteja N (2005). Cold, salinity and drought stresses: an overview. Archives of Biochemistry and Biophysics 444(2):139-158.

Manokaran N (1981a). Survival and growth of rotan sega (Calamus caesius) seedlings at 2 years after planting: I. Line-planted in poorly-drained soil. The Malaysian Forester 44(1):12-22.

Manokaran N (1981b). Survival and growth of rotan sega (Calamus caesius) seedlings at 2 years after planting: I. Line-planted in well-drained soil. The Malaysian Forester 44(4):464-472.

Manokaran N (1982a). Survival and growth of rotan sega (Calamus caesius) seedlings at 2 years after planting: I. Group-planted in poorly-drained soil. The Malaysian Forester 45(1):36-48.

Manokaran N (1982a). Survival and growth of rotan sega (Calamus caesius) seedlings at 5 1/3 years after planting. The Malaysian Forester 45(2):193-202.

Mori T (1980). Growth of Rotan manau (Calamus manan) seedlings under various light conditions. The Malaysian Forester 43(2):187-192.

Peng C (2017). Study on site adaptability of rattan to environment in lowland secondary rain forest in Ganzaling of Hainan Island, China. PhD Thesis, Chinese Academy of Forestry, Beijing.

Qian PX, Li XF, Wu YY, Rao HY, Liu R, Li MQ, Fu T (2015). Influence of shading on growth and physiological characteristics of container seedlings of Acer cinnamomifolium. Jiangsu Journal of Agricultural Sciences 31(3):667-672.

Ren YC, Liu J, Li M, Chen C, Sun XL (2017). Effects of shading stress on antioxidant system of two buffalograss varieties. Acta Agrestia Sinica 25(6):1345-1351.

Ren WW, Qian J, Ma J, Zheng SZ (2000). Comparative study of Leymus chinensis's water content and free proline of different geographic populations under the force of different consistency PEG. Acta Ecologica Sinica 20(2):349-352.

Rousset O, Lepart J (2000). Positive and negative interactions at different life stages of a colonizing species (Quercus humilis). Journal of Ecology 88(3):401-412.

Sack L, Grubb PJ (2002). The combined impacts of deep shade and drought on the growth and biomass allocation of shade tolerant woody seedlings. Oecologia 131(2):175-185.

Sang ZY, Ma LY, Chen FJ (2011). Growth and physiological characteristics of Magnolia wufengensis seedlings under drought stress. Acta Botanica Boreali-Occidentalia Sinica 31(1):0109-0115.

Shao YJ, Shan L, Li GM (2006). Comparison of osmotic regulation and antioxidation between sorghum and maize seedlings under soil drought stress and water recovering conditions. Chinese Journal of EcoAgriculture 14(1):68-70.

Sun S, Zhang XJ, Liu JP, You MH, Guo BH (2018). Synergistic effects of shade and drought on the physiological metabolism and resistance system of Arthraxon hispidus. Acta Ecologica Sinica 38(5):1770-1779.

Sun ZY, Ma YJ, Liu XE, Gao J (2013). Effects of low light environment on the growth and photosynthesis of Calamus nambariensis seedlings. Journal of Southwest Forestry University 33(1):16-20.

Tang GL, Li XY, Lin LS, Li L, Lu JR (2013). Change of different shading on moisture conditions and the physiological response in Alhagi sparsifolia. Chinese Journal of Plant Ecology 37(4):354-364.

Wang C, Lin QP, Gong DH, Li PA, Zhang ZP, Fu GZ (1990). A study on drought adaptability and its physiological mechanism of summer maize. Acta Agriculturae Boreali-Sinica 5(4):54-60.

Wang J, Zhou ZC, Rao LB, Jin GQ, Li JM (2006). Physiological response of Liriodendron Chinese provenances with different phosphorus efficiency under low phosphorus stress. Forest Research 19(4):527531.

Wang KL (2015). Resources and distribution of rattan in China. Plant Science Journal 33(3):320-325. 
Wang ZW, Mou SW, Yan LL, Han QF, Yang BP (2013). Effects of physiological and biochemical characteristics and growth under water stress in seedling of spring maize. Acta Botanica Boreali-Occidentalia Sinica 33(2):0343-0351.

Wei H, Cheng SP, He F, Liang W, Wu ZB, Cheng SP (2014). Growth responses and adaptations of the emergent macrophyte Acorus calamus Linn. to different water-level fluctuation. Journal of Freshwater Ecology 29(1):101-115.

Wu YB, Ye B (2016). Effects of combined elevated temperature and drought stress on anti-oxidative enzyme activities and reactive oxygen species metabolism of Broussonetia papyrifera seedlings. Acta Ecologica Sinica 36(2):403-410.

Xie YG, Liao XF, Zhang DK, Liu JM, Zhao XP, Wen P (2013). Effect of shading treatments on growth and physiological characteristics of Drepanostachyum luodianense. Guangdong Agricultural Sciences 40(12):49-53.

Xue W, Li XY, Zhu JT, Lin LS, Wang YJ (2011). Effects of shading on leaf morphology and response characteristics of photosynthesis in Alhagi sparsifolia. Chinese Journal of Plant Ecology 35(1):82-90.

Yang Y, Liu Q, Han C, Qiao YZ, Yao XQ, Yin HJ (2007). Influence of water stress and low irradiance on morphological and physiological characteristics of Picea asperata seedlings. Photosynthetica 45(4):613-619.

Yang L, He ZJ, Zhao WJ, Jia GF, Lai LM, She H, ... Zheng YR (2017). Growth, physiological, and biochemical responses of Rhodiola kirilowii seedlings to water and shading. Acta Ecologica Sinica 37(14):47064714.

Yin GT, Xu HC, Zhang WL (1988). A preliminary study on the effect of different levels of light intensity on the growth of rattan seedlings. Forest Research 1(5):548-552.

Yin GT, Xu HC, Zhang WL, Fu JG, Zeng BS (1993). Study on the collection and introduction of rattan species. Forest Research 6(6):609-617.

Yuan XK, Yang ZQ, Li YX, Liu Q, Han W (2016). Effects of different levels of water stress on leaf photosynthetic characteristics and antioxidant enzyme activities of greenhouse tomato. Photosynthetica 54(1):28-39.

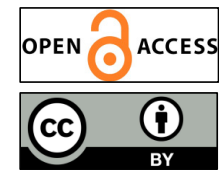

The journal offers free, immediate, and unrestricted access to peer-reviewed research and scholarly work. Users are allowed to read, download, copy, distribute, print, search, or link to the full texts of the articles, or use them for any other lawful purpose, without asking prior permission from the publisher or the author.

License - Papers published in Notulae Botanicae Horti Agrobotanici Cluj-Napoca are Open-Access, distributed under the terms and conditions of the Creative Commons Attribution (CC BY) License.

(C) Articles by the authors; UASVM, Cluj-Napoca, Romania. The journal allows the author(s) to hold the copyright/to retain publishing rights without restriction. 